Civilization and Enlightenment 


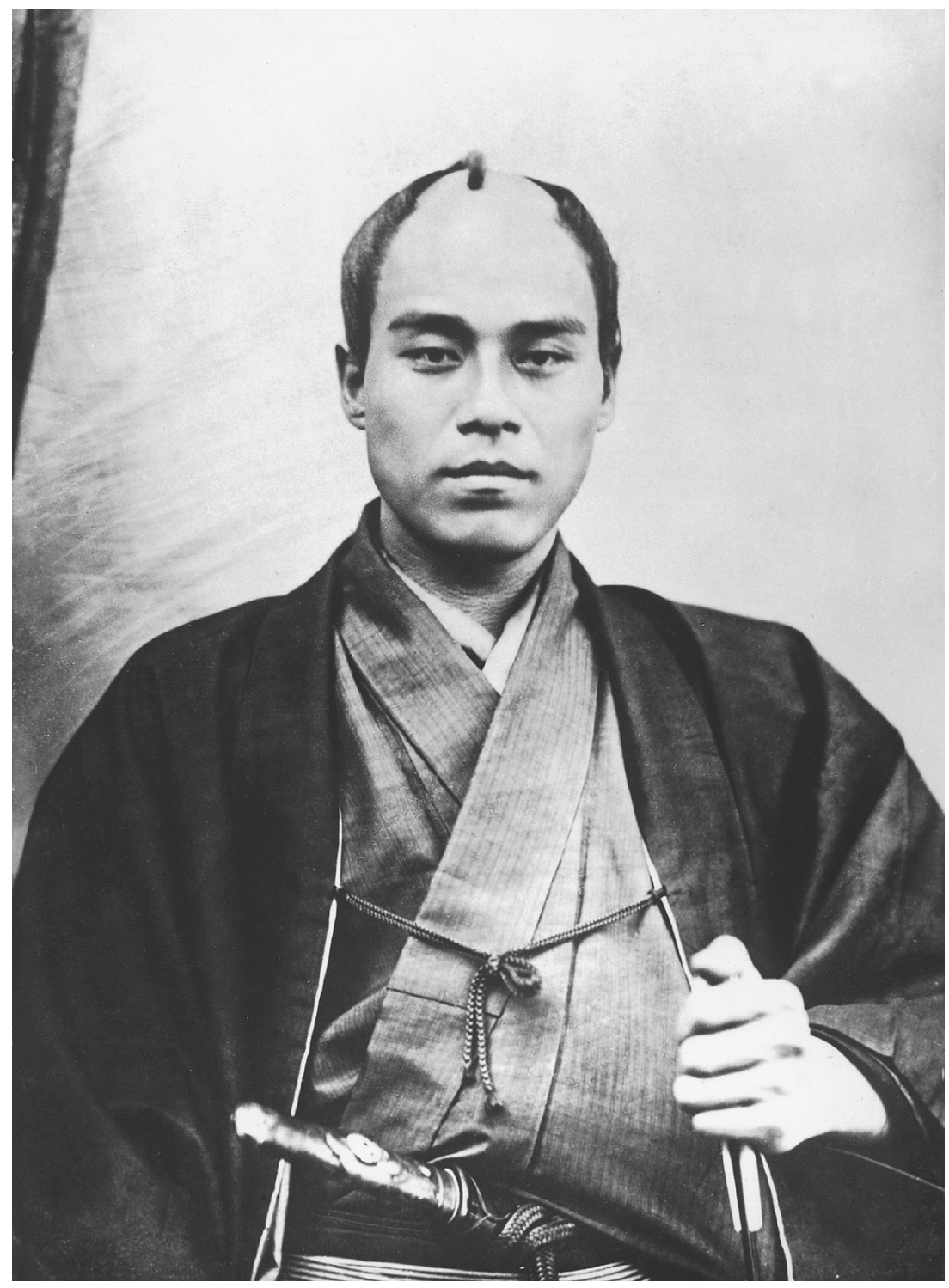




\section{Civilization and Enlightenment}

THE EARLY THOUGHT OF

FUKUZAWA YUKICHI

Albert M. Craig

HARVARD UNIVERSITY PRESS

Cambridge, Massachusetts, and London, England 2009 
Copyright (C) 2009 by the President and Fellows of Harvard College All rights reserved

Printed in the United States of America

Frontispiece: Fukuzawa in Paris, 1862. Little more than three years after leaving the Ogata school of Dutch Studies in Osaka, Fukuzawa was appointed an official interpreter of the 1862 bakufu mission to Europe.

\section{Library of Congress Cataloging-in-Publication Data}

\section{Craig, Albert $M$.}

Civilization and enlightenment : the early thought of Fukuzawa Yukichi / Albert M.

Craig.

p. $\mathrm{cm}$.

Includes bibliographical references and index.

ISBN 978-0-674-03108-1 (cloth : alk. paper)

1. Fukuzawa, Yukichi, 1835-1901. I. Title.

LB775.F82C73 2009

370.92—dc22 2008027462 
FOR TERUKO 
